\title{
21406 不整地路面走行時における人間-自転車系の力学 Dynamics of Human-Bicycle System during Off-Road Cycling
}

\author{
○学 深田 亮介（埼玉大） 正 鞆田 顕章（埼玉大） 正 渡邊 鉄也（埼玉大） \\ Ryosuke FUKADA, Saitama University, 255 Shimo-Okubo, Sakura-ku, Saitama-shi, Saitama \\ Akinori TOMODA, Saitama University \\ Tetsuya WATANABE, Saitama University
}

\begin{abstract}
This study deals with dynamic models of a human body and a bicycle during off-road cycling for optimization of the vibration characteristics of bicycle frame. A stability of a bicycle and a ride comfort depend on the characteristics of human-bicycle system. In addition, the mass ratio of a human body to a bicycle is extremely large as compared with other vehicles. Therefore, rider's posture becomes very important. In the present paper, the modal frequency and damping ratio of first mode of human body in vertical direction when the bicycle goes over an obstacle are estimated by experimental modal analysis. Especially, influence of condition of arms is clarified.
\end{abstract}

Key Words: Bicycle, Modeling, Human-bicycle System, Irregular Vibration

\section{1. 緒言}

自転車は，走行時において化石燃料を一切消費しないため， 自動車や原動機付 2 輪車と比較して経済的かつ環境的に優れ た移動用機械である.また自転車による運動は付加調整が容 易であるため, 運動機能が低下している者であっても安全か つ安心して取り組めるものである.しかし，運動用に特化し た自転車の多くは高剛性のフレームを有し, 乗車中の振動暴 露により快適に利用できない場合がある.

自転車車体の振動特性は, 系の質量, 剛性, 減衰係数によ つて決定され，走行時の乗り心地や安定性に影響を及ぼす. そのため車体設計時においては,これらの最適化を図ること が極めて重要である.ここで, 過去の研究(1)では車体の詳細 な力学モデルを検討したものがあるが，人間については集中 質量等で表現した簡易なモデルが用いられてきた。しかし， 車体に対する人間の質量比は他の移動用機械と比較して極 端に大きいため, 人間の振動特性や上半身の姿勢変化は系の 安定性に影響を及ぼすことが予想される.

そこで本研究では, 自転車乗車時における人間の上半身の 姿勢変化に注目し, 人間及び車体の振動特性を求めるととも に, 人間及び車体の詳細な力学モデルを構筑することを目的 とする，本報では，系への振動入力が大きい不整地路面走行 時において, 人間の上腕-前腕部の状態変化による系の振動 特性への影響を検討する.

\section{2. 自転車乗車時における人間の振動特性 \\ 2. 1 実験方法}

自転車乗車時における人間の振動特性を取得するための 実験概要図を図 1 に示す。不整地路面を模擬するため，三角 形断面状（幅 $69 \mathrm{~mm} ，$ 高さ $36 \mathrm{~mm}$ ） の障害物を整地路面上に 設置した. 障害物通過時における自転車フレーム部および人 閒頭部の鉛直方向加速度を図中の加速度センサ 1,2 により取 得する. 加速度データは, 車体後部の荷台に固定されたデー タロガーにより記録する．自転車の前後輪におけるタイヤ空 気圧（ゲージ圧）は $250 \mathrm{kPa}$ とし，実験開始前に調整を行っ た。また障害物通過時における走行速度の目標值は $10 \mathrm{~km} / \mathrm{h}$ とし, 各被験者にはハンドル部に設置した速度計により走行
速度を調整するよう指示した. 本報では, 表 1 に示される 7 名の被験者について, 肘を伸ばした状態及び曲げた状態の 2 条件で走行実験を行い, 条件の違いによる人間の振動特性の 変化について検討した。

\section{2 実験結果}

実験結果の一例として, 被験者 7 における頭部及びフレー 厶部の鉛直方向加速度の時刻歴波形を図 2 に示す. フレーム の最大加速度に対する頭部の最大加速度は小さくなってお り，振動が低减されていることが分かる。ここで本報では， 自転車乗車時における人間の振動特性を簡易的に把握する ため, 人間を 1 自由度減衰系として考える. 1 自由度減衰系 の伝達関数 $G(\omega)$ の式は,

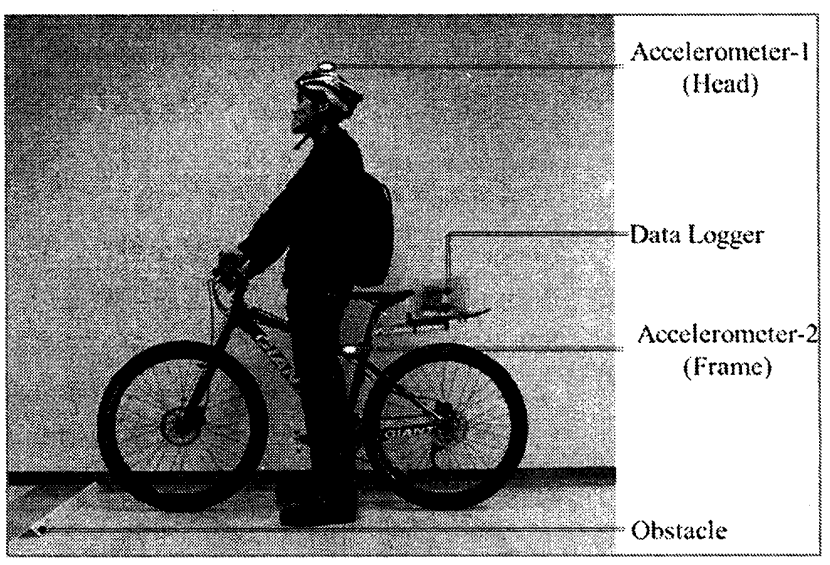

Fig. 1 Experimental Setup

Table 1 Subjects

\begin{tabular}{|c|c|c|}
\hline Subject & Tall [cm] & Weight [kg] \\
\hline 1 & 175 & 63 \\
\hline 2 & 168 & 60 \\
\hline 3 & 168 & 51 \\
\hline 4 & 187 & 85 \\
\hline 5 & 170 & 57 \\
\hline 6 & 173 & 63 \\
\hline 7 & 174 & 60 \\
\hline
\end{tabular}




$$
G(\omega)=\frac{1 / k}{1-\beta^{2}+2 j \zeta \beta}, \beta=\frac{\omega}{\Omega}
$$

であり， $k$ はばね定数， $\Omega$ は固有振動数である.また $\zeta$ は 减衰比であり, $m$ を質量, $c$ を粘性減衰係数とした時の固有 振動数及び減衰比は,

$$
\Omega=\sqrt{\frac{k}{m}}, \zeta=\frac{c}{2 \sqrt{m k}}
$$

となる. 式(1)を用いて, 各部の加速度の時刻歴波形から取得 した自転車-人間間の伝達関数に曲線適合を行うことにより 系の卓越振動数及び減衰比を算出した

図 3 は被験者 7 における自転車-人間間の伝達関数である. 図中の実線は时を伸ばした状態の実験結果であり，点線は曲 げた状態の結果である。ここで，座位状態における人間の鉛 直方向の卓越振動数は，頭部で 4 $5 \mathrm{~Hz}$ ，肩部で $5 \sim 6 \mathrm{~Hz}$, 腰部 で $4 \mathrm{~Hz}$ 近傍に存在することが報告されており ${ }^{(2)}$, 本研究では この振動数帯に注目する.各被験者の伝達関数の $4 \sim 6 \mathrm{~Hz}$ にお いて式(1)を用いて曲線適合し, 得られた卓越振動数, 減衰比, それらの変化率を表 2 に示す。

図 3 から, 时を伸ばした状態から曲げる状態へ変化させる ことで 4 6Hz 帯の伝達関数のピーク值が大きくなり, またピ 一ク振動数が低下していることが分かる。これらの傾向はほ ぼすべての被験者に現れた。

ピーク值が大きくなったことに関しては，人体脊椎系の 1 次振動モードが現れたためだと考えられる，中井らは座位状 態の人体春椎系の実験モード解析を行い，1 3 次のモード形 状を明らかにしている(3)。 その1 次モードは肩部及び頭部の 振幅が比較的大きく，振動数 $4.75 \mathrm{~Hz}$ ，減衰比 $37 \%$ であり，本 実験で得られた伝達関数のピーク振動数と近い值となって いた．本実験の条件として肘の曲げ伸ばしを挙げているが， 肘を伸ばした状態では时及び肩が拘束され，肘を曲げること でその拘束が弱まっていることが考えられる．拘束が弱まる ことにより上記の1次振動モードが励起されやすくなったと 考えられる.

表 2 に示される卓越振動数及び減衰比の低下に関しては, 平均でそれぞれ $3.63 \%$, 約 30\%の低下という結果を得た。 卓 越振動数においては式(2)より, 时を曲げることで肘の剛性が 低下しそれに伴い，低下したものと考えられる．しかし減衰 比においては式(2)によれば増加するはずであるが, 実験結果 は 30\%の低下という結果を得ている.また上記の 1 次振動モ 一ドの減衰比との差も大きい。この原因として, 肘の曲げ伸 ばしによる姿勢変化によって背筋の剛性值及び減衰係数が 変化しており，それが影響を及ぼしている可能性がある。ま た非線形性が強い系であることも原因として考えられる。

今後の方針として, 本報における実験では鉛直方向加速度 のみ取得しているが，実験中の人間頭部の挙動を観察してみ ると, 鉛直方向並びに進行方向の振動も大きく現れていたた め, 人間頭部の挙動は進行方向の振動も含めて検討していく 必要があると考える.また人間への入力はハンドル及びサド ルの 2 入力であり，それらの振動情報も取得し， 2 入力に対 する人間頭部の応答を検討していく必要があると考える。

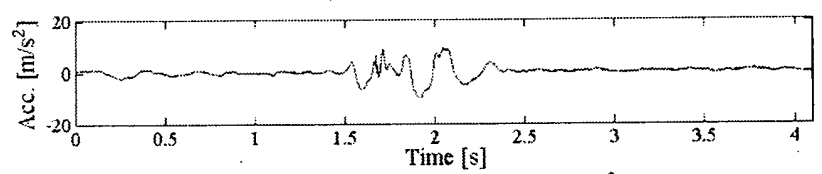

(a) Accelerometer-1 (Max $\left.10.05\left[\mathrm{~m} / \mathrm{s}^{2}\right]\right)$

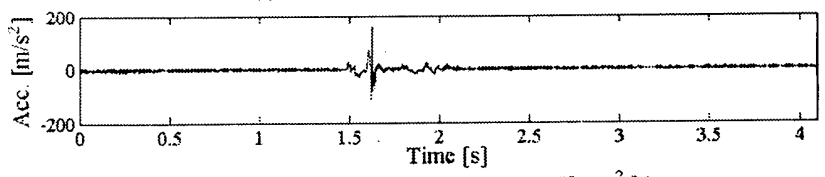

(b) Accelerometer-2 (Max:158.47[ $\left.\left.\mathrm{m} / \mathrm{s}^{2}\right]\right)$

Fig. 2 Acceleration (Subject-7)

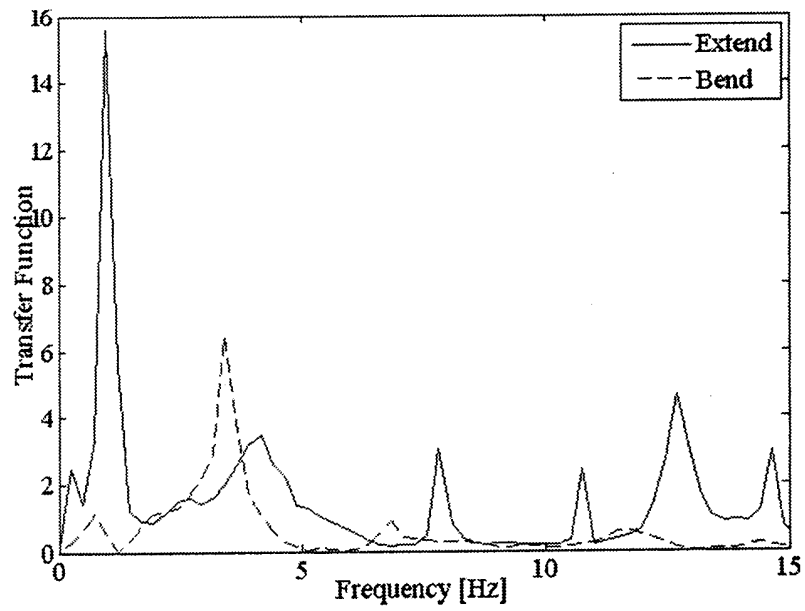

Fig. 3 Transfer Function (Subject-7)

Table 2 Dominant Frequency and Damping Ratio

\begin{tabular}{|c|c|c|c|c|c|c|}
\hline \multirow{2}{*}{ Subject } & \multicolumn{2}{|c|}{ Frequency [Hz] } & \multirow{2}{*}{ Change[\%] } & \multicolumn{2}{c|}{ Damping Ratio [\%] } & \multirow{2}{*}{ Change[\%] } \\
\cline { 2 - 3 } & Extend & Bend & & Extend & Bend & \\
\hline 1 & 4.27 & 4.48 & 4.76 & 4.35 & 3.03 & -30.3 \\
\hline 2 & 4.31 & 4.15 & -3.77 & 4.68 & 5.97 & 27.8 \\
\hline 3 & 4.07 & 3.42 & -16.0 & 7.91 & 5.52 & -30.1 \\
\hline 4 & 4.15 & 4.03 & -2.94 & 13.2 & 4.28 & -67.6 \\
\hline 5 & 3.74 & 3.66 & -2.17 & 6.02 & 4.98 & -17.3 \\
\hline 6 & 3.99 & 4.11 & 3.06 & 6.62 & 4.70 & -29.1 \\
\hline 7 & 3.91 & 3.58 & -8.33 & 8.38 & 3.44 & -59.0 \\
\hline
\end{tabular}

\section{3. 結言}

本報では，自転車乗車時における人間の振動特性について 検討した．その結果，以下のことが分かった。

・人間-自転車系において腕は系の振動特性を変化させる要 素である。

-人間-自転車系における人間の上半身を 1 自由度系と仮定 した時の固有振動数は $4 \mathrm{~Hz}$ 近傍に存在する.

\section{謝辞}

本研究は, 競輪（財団法人 JKA 平成 23 年度機械振興補助事 業）の補助を受けて実施した。ここに記して，謝意を表す。

\section{参考文献}

(1) J.D.G.Kooijman, et al., A Bicycle Can Be Self-Stable Without Gyroscopic or Caster Effects, SCIENCE, Vol.332(2011), pp.339-342.

(2) 岡村, 小泉, 辻内, 小濱, 水平・垂直連成振動における人 体動特性を考慮した乗り心地評価，機論，68-674C(2002), pp.2865-2871.

(3) 中井, 吉村, 玉置, 人体脊椎系の実験モード解析, 機論, 71-707C(2005), pp.2328-2336. 